\title{
Occupational illnesses in the 2009 Zambian labour force survey
}

Adamson S Muula ${ }^{1 *}$, Emmanuel Rudatsikira², Seter Siziya ${ }^{3}$

\begin{abstract}
Background: Occupational health has received limited research attention in the Southern African Development Community (SADC). Much of the published data in this region come from South Africa and little has been reported north of the Limpopo. The present study was conducted to estimate the burden of occupational illnesses in Zambia and assess factors associated with their occurrence.

Methods: Data were obtained from the Zambian Labour Force Survey of 2009. Frequencies were used to estimate the prevalence of occupational diseases. Logistic regression analyses were conducted to determine the associations between demographic, social and economic factors and reported illness resulting from occupational exposures. Odds ratios (OR) from bivariate analyses and adjusted odds ratios (AOR) from the multivariate analysis together with their 95\% Confidence Intervals (Cl) are reported.

Results: Data on 59,118 persons aged 18 years or older were available for analysis, of which 29805 (50.4\%) were males. The proportions of the sample that reported to have suffered from an occupational illness were $12.7 \%$ among males and $10.4 \%$ among females $(p<0.001$ ). Overall the proportions of respondents who reported suffering from fatigue, fever and chest infections were $38.8 \%, 21.7 \%$ and $17.1 \%$, respectively. About two thirds (69.7\%) of the study participants had stayed away from work due to the illness suffered at work; there was no sex differences ( $p=0.216)$. Older age, being male, lower education level, married/cohabiting or once married (separated/divorced/widowed), and paid employee or employer/self employed were positively associated with having suffered from illness.

Conclusions: The findings from this study call for urgent effort for specific measures to prevent and mitigate the effects of occupational injuries. These interventions may include: public health campaigns, enforcement or change in work policies and regulations. Special attention may have to be made towards those who were more likely to suffer from occupational illnesses.
\end{abstract}

\section{Background}

Research on occupational illnesses and the pursuit for improved occupational health have largely been reported from high and middle income nations. Data from low income nations are often unavailable and when they do, are incomplete, unreliable or generally describe poor occupational health situations among workers.

There has been growing literature on occupational illnesses in health care workers and agriculture workforce [1-7]. Health workers are exposed to infections or diseases such as tuberculosis, Hepatitis B, human

\footnotetext{
* Correspondence: amuula@medcol.mw

'Department of Public Health, Division of Community Health, College of

Medicine, University of Malawi, Blantyre, Malawi

Full list of author information is available at the end of the article
}

immunodeficiency virus and acquired immunodeficiency syndrome. Meanwhile workers in certain types of agriculture suffer from ill-health resulting from exposure to animals, micro-organisms, plant material dust or chemicals. This may be important in developing nations like Zambia where the majority of the population are in the agricultural sector.

Much of the data on occupational health and safety from the Southern African Development Community (SADC) are from South Africa. The SADC comprises the following countries: Angola, Botswana, Democratic Republic of Congo, Lesotho, Madagascar, Malawi, Mauritius, Mozambique, Namibia, Seychelles, South Africa, Swaziland, Tanzania, Zambia and Zimbabwe. There is paucity of data from the rest of the region,
C Biomed Central

() 2010 Muula et al; licensee BioMed Central Ltd. This is an open access article distributed under the terms of the Creative Commons Attribution License (http://creativecommons.org/licenses/by/2.0), which permits unrestricted use, distribution, and reproduction in any medium, provided the original work is properly cited. 
especially north of the Limpopo. Hence the negative impact of poor work conditions is unappreciated and the scientific basis for interventions and policy formulation is to a great extent absent. Loewenson [8], however, has argued that "While the share of world trade to the world's poorest countries has decreased, workers in these countries increasingly find themselves in insecure, poor quality jobs, sometimes involving technologies which are obsolete or banned in industrialized countries". Examples of obsolete technologies include unshielded dangerous machinery and hazardous substances known to cause increase in occupational diseases and accidents [9]. Loewenson [8] further argued that "The occupational illness which results is generally less visible and not adequately recognized as a problem in low income countries." The present study was carried out to assess the burden of occupational illnesses and associated factors in the Zambian workforce.

\section{Methods}

We obtained data from the Central Statistical Office (CSO) [Zambia] through the Work and Health in Southern Africa (WAHSA) Project. A detail on the methodology that is used in the Zambian labour force survey (LFS) is published elsewhere [10]. However, we briefly describe the methodology below.

\section{Study design and setting}

Cross sectional labour force surveys are conducted from time to time by Central Statistical Office of Zambia. The target population for LFS is persons of age 15 years or older. However, for our study we selected only persons of age 18 years or older and currently in employment (whether paid or not).

\section{Sample size and sampling}

The sample size aims to enroll households and this is designed in such a way as to have adequate power to produce estimates for the entire country, urban and rural areas, and for each province. Zambia has nine provinces which are: Central, Copper Belt, Eastern, Luapula, Lusaka, Northern, North-Western, Southern and Western. The administrative hub of the country is in Lusaka province in which the capital city, Lusaka, is situated. Hence, the major economic sector in Lusaka province is the Service sector. The Copper Belt province as the name implies is the seat of Zambia's copper mining efforts. Fishing is the main occupation in Luapula and Western provinces. Peasantry farming (mainly cultivating maize, cotton and groundnuts) is the major economic activity in the rest of the provinces.

A two stage cluster sampling technique is used to draw sampling units. The primary sampling units are
Census Enumeration Areas (CEAs), identified from a sampling frame compiled from the 2000 population and housing census. In the second stage of sampling, households are systematically sampled in each CEA and all persons of age 15 years or older in the household are requested to participate in the survey.

\section{Questionnaire}

The composition of the questionnaire used in LFS varies from survey to survey. In the 2009, the Central Statistical Office incorporated questions on: health outcomes, work sector and conditions, work place facilities, work-related injuries and history of compensation from occupational injuries. The design of the questions and definitions used conform to the requirements set by international bodies such as the International Labour Organization (ILO). Questionnaires were administered in the homes of the survey participants by trained research assistants.

\section{Data analysis}

Analyses were conducted using SPSS version 11.5.0. Frequencies were used to estimate the prevalence of occupational illnesses. The Chi-square test was used to compare proportions. The cut off point for statistical significance was set at the 5\% level. Logistic regression analyses (bivariate and multivariate) were conducted to determine the level of association between demographic, social and economic factors and occupational illnesses suffered. We used Deviation as the contrast, and the first category of the explanatory variables as the reference. Odds ratios (OR) from bivariate analysis and adjusted odds ratios (AOR) from a multivariate analysis (backward logistic regression) together with their 95\% Confidence Intervals (CI) are reported.

\section{Results}

\section{Socio-demographic description of the sample}

Data on 59,118 study participants of age 18 years or older were available for analysis of which 29,805 (50.4\%) were males. Sex was not recorded in 5 participants. The socio-demographic distributions of participants by sex are shown in Table 1. Overall, female participants tended to be younger, and once married (separated, divorced or widowed). More female (61.2\%) than male (43.4\%) participants had completed no more than 7 years of formal education. While more male (55.7\%) than female $(38.1 \%)$ respondents were self employed, a higher proportion of females $(52.5 \%)$ were unemployed family workers compared to males $(21.0 \%)$.

\section{Illnesses suffered at workplace}

The proportions of males and females who reported to have suffered from any illness known or suspected to result from work in the past 12 months prior to the 
Table 1 Socio-demographic characteristics of study participants in the Zambia Labour Survey 2009

\section{Characteristic}

\section{Age (years)}

5-9

$10-14$

15-19

$20-24$

$25-34$

35-44

45-54

$55+$

Total

\section{Marital status}

Never married

Married

Separated

Divorced

Widowed

Cohabiting

Total

\section{Completed years in formal school}

1-3

4-7

8-9

10-12

$13+$

Total

Province

Central

Copperbelt

Eastern

Luapula

Lusaka

Northern

North-Western

Southern

Western

Total

Current* employment status

Self employed

Employed

Paid employee

Unpaid family worker

Other

Total

Current employer

Central government

Local government

$\begin{array}{lll}\text { Male } & \text { Female } & \text { Total } \\ \text { n (\%) } & \text { n (\%) } & \text { n (\%) }\end{array}$

$11654(18.2) \quad 11656(17.8) \quad 23310(18.0)$

$11099(17.3) \quad 10958(16.7) \quad 22057(17.0)$

$9837(15.3) \quad 9421(14.4) \quad 19258(14.8)$

$6435(10.0) \quad 7585(11.6) \quad 14020(10.8)$

$10399(16.2) \quad 11268(17.2) \quad 21667(16.7)$

$6802(10.6) \quad 6699(10.2) \quad 13501(10.4)$

$3715(5.8) \quad 3729(5.7) \quad 7444(5.7)$

$4178(6.5) \quad 4330(6.6) \quad 8508(6.6)$

$64119(100) \quad 65646(100) \quad 129765(100)$

$24364(50.8) \quad 19143(38.7) \quad 43507(44.6)$

$21501(44.8) \quad 22459(45.4) \quad 43960(45.1)$

$476(1.0) \quad 1058(2.1) \quad 1534(1.6)$

$752(1.6) \quad 2369(4.8) \quad 3121(3.2)$

$821(1.7) \quad 4356(8.8) \quad 5177(5.3)$

$70(0.1) \quad 102(0.2) \quad 172(0.2)$

$47984(100) \quad 49487(100) \quad 97471(100)$

$348(0.7) \quad 373(0.7) \quad 721(0.7)$

$10331(19.5) \quad 11828(23.1) \quad 22159(21.3)$

$20239(38.2) \quad 22179(43.3) \quad 42418(40.7)$

$10312(19.5) \quad 9060(17.7) \quad 19372(18.6)$

$9820(18.6) \quad 6541(12.8) \quad 16361(15.7)$

$1887(3.6) \quad 1246(2.4) \quad 3133(3.0)$

$52937(100) \quad 51227(100) \quad 104164(100)$

$6147(9.6) \quad 6165(9.4) \quad 12312(9.5)$

$10349(16.1) \quad 10397(15.8) \quad 20746(16.0)$

$7978(12.4) \quad 8085(12.3) \quad 16063(12.4)$

$5937(9.3) \quad 5970(9.1) \quad 11907(9.2)$

$7162(11.2) \quad 7260(11.1) \quad 14422(11.1)$

$8080(12.6) \quad 8208(12.5) \quad 16288(12.6)$

$4378(6.8) \quad 4407(6.7) \quad 8785(6.8)$

$8485(13.2) \quad 8830(13.5) \quad 17315(13.3)$

$5603(8.7) \quad 6324(9.6) \quad 11927(9.2)$

$64119(100) \quad 65646(100) \quad 129765(100)$

$17050(42.3) \quad 11565(29.7) \quad 28615(36.1)$

$126(0.3) \quad 67(0.2) \quad 193(0.2)$

$7641(18.9) \quad 3253(8.4) \quad 10894(13.8)$

$15406(38.2) \quad 23896(61.5) \quad 39302(49.6)$

$116(0.3) \quad 99(0.3) \quad 215(0.3)$

$40339(100) \quad 38880(100) \quad 79219(100)$

$1549(3.8) \quad 924(2.4) \quad 2473(3.1)$

$217(0.5) \quad 126(0.3) \quad 343(0.4)$


Table 1 Socio-demographic characteristics of study participants in the Zambia Labour Survey 2009 (Continued)

\begin{tabular}{|c|c|c|c|}
\hline Parastatal/State owned firm & $352(0.9)$ & $95(0.2)$ & $447(0.6)$ \\
\hline Private & $7382(18.3)$ & $3529(9.1)$ & $10911(13.8)$ \\
\hline NGO** or church & $251(0.6)$ & $153(0.4)$ & $404(0.5)$ \\
\hline International organization & $49(0.1)$ & $24(0.1)$ & $73(0.1)$ \\
\hline Household & $30542(75.7)$ & $34032(87.5)$ & $64574(81.5)$ \\
\hline Total & $40342(100)$ & $38883(100)$ & $79225(100)$ \\
\hline \multicolumn{4}{|l|}{ Current number of employees at place of work } \\
\hline $5+$ & $11907(29.6)$ & $8128(21.0)$ & $20035(25.4)$ \\
\hline Total & 40162 & 38646 & 78808 \\
\hline \multicolumn{4}{|l|}{ Current employment activity } \\
\hline In paid employment/business & $18489(29.1)$ & $10884(16.7)$ & $29373(22.8)$ \\
\hline In paid employment but temporarily not working due to illness, leave, industrial dispute or on study & $235(0.4)$ & $151(0.2)$ & $386(0.3)$ \\
\hline Working without pay & $11942(18.8)$ & $16991(26.1)$ & $28933(22.5)$ \\
\hline Not working but looking for work/business & $1533(2.4)$ & $1118(1.7)$ & $2651(2.1)$ \\
\hline Not working and not looking for work but available for work/business & $4647(7.3)$ & $5300(8.1)$ & $9947(7.7)$ \\
\hline Housewife/Homemaker & $244(0.4)$ & $4580(7.0)$ & $4824(3.7)$ \\
\hline Retired & $169(0.3)$ & $53(0.1)$ & $222(0.2)$ \\
\hline In school (full time student) & $16479(25.9)$ & $15448(23.7)$ & $31927(24.8)$ \\
\hline Too old to work & $654(1.0)$ & $1113(1.7)$ & $1767(1.4)$ \\
\hline Too young to work & $7361(11.6)$ & $7346(11.3)$ & $14707(11.4)$ \\
\hline Not working, not looking for work and not available for work for other reasons & $1878(3.0)$ & $2184(3.4)$ & $4062(3.2)$ \\
\hline Total & $63631(100)$ & $65168(100)$ & $128799(100)$ \\
\hline
\end{tabular}

* status in the previous 7 days to the survey.

** Non Governmental Organization.

Note: Numbers not adding up due to missing information.

survey were $12.7 \%$ and $10.4 \%$, respectively. Overall the proportions of respondents who reported suffering from fatigue, fever and chest infections were $38.8 \%, 21.7 \%$ and $17.1 \%$, respectively. About two thirds $(69.7 \%)$ of the study participants had stayed away from work due to the illness suffered at work; there was no sex differences $(\mathrm{p}=0.216)$, see Table 2 .

Table 3 shows the proportions of serious illnesses suffered in relation to work conditions. Fatigue was the most common illness among persons exposed to vibrations $(31.7 \%)$, breathing in smoke, fumes, powder or dust $(40.1 \%)$, pesticide $(37.6 \%)$, skin contact with chemicals (38.4\%), handling infectious materials or waste (26.0\%), and lifting heavy objects (39.5\%). Chest infections were common among persons exposed to temperatures causing perspiration (26.8\%), breathing in vapours from other chemicals such solvents and thinners (27.0\%), noise (24.2\%), and radiation (21.8\%). Fever was most common among persons exposed to low temperatures (26.8\%).

\section{Multivariate analysis of factors associated with illnesses suffered at workplace}

All the factors that were significantly associated with having suffered from illness arising from place of work in bivariate analyses remained significant in a multivariate analysis (Table 3). Older age, male, lower education level, married/cohabiting or once married (separated/ divorced/widowed), and paid employee or employer/self employed were positively associated with having suffered from illness.

\section{Discussion}

The labour force survey is one of the largest studies conducted in Zambia. Female respondents tended to be less educated, married or were once married and unpaid family workers. More than $10 \%$ of workers reported illness they considered to be work related, for which $70 \%$ of those affected stayed away from work.

We found that respondents with more education were less likely to suffer from illnesses compared to respondents with little or no education. In a study conducted among Nigerian welders, Sabitu et al (2009) reported that only $20 \%$ of those who had no formal education were aware of occupation hazards and safety measures compared to $77.6 \%$ among those who has primary education and $85.0 \%$ among those who had secondary education [11]. People with education are more knowledgeable to avoid harmful exposures, and as a result may be less 
Table 2 Serious illness suffered at workplace in past 12 months prior to the survey

\begin{tabular}{|c|c|c|c|}
\hline & Male & Female & Total \\
\hline Characteristic & n (\%) & n (\%) & n (\%) \\
\hline \multicolumn{4}{|c|}{ Suffered from any illnesses due to work in past 12 months } \\
\hline Yes & $3660(12.0)$ & $3027(9.6)$ & $6687(10.8)$ \\
\hline Total & 30558 & 31525 & 62083 \\
\hline \multicolumn{4}{|c|}{ Most serious illness suffered from due to work in past 12 months } \\
\hline Skin problems & $151(4.1)$ & $110(3.6)$ & $261(3.9)$ \\
\hline Respiratory problems & $268(7.3)$ & $142(4.7)$ & $410(6.1)$ \\
\hline Allergies & $41(1.1)$ & $43(1.4)$ & $84(1.3)$ \\
\hline Diarrhoea & $99(2.7)$ & $139(4.6)$ & $238(3.6)$ \\
\hline Fatigue & $1360(37.2)$ & $1235(40.8)$ & $2595(38.8)$ \\
\hline Chest infections & $691(18.9)$ & $428(14.1)$ & $1119(16.7)$ \\
\hline Fever & $738(20.2)$ & $731(24.2)$ & $1469(22.0)$ \\
\hline Other & $312(8.5)$ & $198(6.5)$ & $510(7.6)$ \\
\hline Total & $3660(100)$ & $3026(100)$ & $6686(100)$ \\
\hline \multicolumn{4}{|c|}{ Stayed away from work due to above Illness } \\
\hline Yes & $2503(68.4)$ & $2133(70.5)$ & $4636(69.4)$ \\
\hline Total & 3659 & 3025 & 6684 \\
\hline \multicolumn{4}{|c|}{ Days away from work due to above IIIness } \\
\hline$<7$ & $1103(44.4)$ & $963(45.6)$ & $2066(45.0)$ \\
\hline 7-13 & 735 (29.6) & $604(28.6)$ & $1339(29.1)$ \\
\hline $14-20$ & $322(13.0)$ & $250(11.8)$ & $572(12.4)$ \\
\hline $21+$ & $325(13.1)$ & $293(13.9)$ & $618(13.4)$ \\
\hline Total & $2485(100)$ & $2110(100)$ & $4595(100)$ \\
\hline \multicolumn{4}{|c|}{ Received compensation from work as a result of the above illness } \\
\hline Yes & $202(5.6)$ & $63(2.1)$ & $265(4.0)$ \\
\hline Total & 3635 & 3011 & 6646 \\
\hline
\end{tabular}

Note: Numbers not adding up due to missing information.

likely to fall ill. Educated workers may also be employed in more skilled but less hazardous jobs, and as a result may be less likely to suffer from illnesses.

We also found that workers who were self employed had missed more workdays as a result of work-related illness compared to those employed by others. There are several possible reasons why this may be the case. Firstly, it is possible that self-employed workers are less likely to pay attention to safe work environments as they may be accountable only to themselves. As a consequence, they may be more likely to suffer occupation associated illnesses. Secondly, it is possible the selfemployed persons have more opportunity to excuse themselves from work due to illness while it may be harder for those who are employed by others.

Results from our study suggest that males are more likely to suffer from serious illnesses than females. Men may be more likely to work in harsher environment than females, and this may partly explain the observed sex difference in the proportion of serious illnesses suffered.

\section{Limitations of the study}

There are several limitations for this present study. Data were collected through self-reports, and our results may be biased to the extent that the participants misreported either intentionally or unintentionally. Since the design of the data collection was cross sectional, it is not possible to assign causation to any of the explanatory variables. We did not have information on the underlying medical conditions [12], and stress [13] to verify the illnesses reported by the respondents as resulting from their workplaces. Information on how the sample size was determined or the participation rate was not obtained from the CSO.

\section{Conclusion}

The prevalence of work-related illness was high in Zambia, and associated with significant levels of absence from work. The data provide good social and socioeconomic grounds to motivate for improvements to working conditions to prevent these occurrences as 
Table 3 Demographic, social and economic factors associated with serious illnesses

\begin{tabular}{|c|c|c|c|c|}
\hline \multirow{3}{*}{$\begin{array}{l}\text { Factor } \\
\text { Age (years) }\end{array}$} & \multicolumn{2}{|c|}{ Suffered serious illness } & \multirow{2}{*}{$\begin{array}{r}\text { Bivariate } \\
\text { OR }(95 \% \mathrm{cCl}) \\
\end{array}$} & \multirow{2}{*}{$\begin{array}{r}\text { Multivariate } \\
\text { AOR }(95 \% \mathrm{Cl})\end{array}$} \\
\hline & Total & n (\%) & & \\
\hline & & & & \\
\hline$<15$ & 45385 & $69(0.2)$ & 1 & 1 \\
\hline $15-19$ & 19262 & $221(1.1)$ & $0.55(0.49,0.62)$ & $0.69(0.60,0.81)$ \\
\hline $20-24$ & 14023 & 508 (3.6) & $1.78(1.63,1.95)$ & $1.69(1.51,1.89)$ \\
\hline $25-34$ & 21669 & $1458(6.7)$ & $3.41(3.18,3.67)$ & $1.95(1.76,2.17)$ \\
\hline $35+$ & 29459 & $2382(8.1)$ & $4.16(3.89,4.45)$ & $2.03(1.83,2.26)$ \\
\hline \multicolumn{5}{|l|}{ Sex } \\
\hline Female & 65646 & $2131(3.2)$ & 1 & 1 \\
\hline Male & 64119 & $2507(3.9)$ & $1.01(1.07,1.13)$ & $1.11(1.07,1.16)$ \\
\hline \multicolumn{5}{|l|}{ Completed years in school } \\
\hline$<3$ & 22983 & $466(2.0)$ & 1 & 1 \\
\hline $4-7$ & 42508 & $1878(4.4)$ & $1.33(1.27,1.40)$ & $1.24(1.18,1.31)$ \\
\hline 8-9 & 19405 & $825(4.3)$ & $1.28(1.20,1.36)$ & $0.98(0.92,1.05)$ \\
\hline $10+$ & 19527 & $647(3.3)$ & $0.99(0.92,1.05)$ & $0.60(0.56,0.65)$ \\
\hline \multicolumn{5}{|l|}{ Current marital status } \\
\hline never married & 43512 & $577(1.3)$ & 1 & 1 \\
\hline married/cohabiting & 44134 & $3336(7.6)$ & $1.87(1.79,1.95)$ & $1.24(1.17,1.32)$ \\
\hline separated/divorced/widowed & 9833 & $700(7.1)$ & $1.75(1.65,1.86)$ & $1.17(1.08,1.27)$ \\
\hline \multicolumn{5}{|l|}{ Province } \\
\hline Western & 11928 & $200(1.7)$ & 1 & 1 \\
\hline Copperbelt & 20748 & $661(3.2)$ & $0.97(0.90,1.04)$ & $1.19(1.09,1.30)$ \\
\hline Eastern & 16065 & $295(1.8)$ & $0.55(0.49,0.61)$ & $0.47(0.41,0.53)$ \\
\hline Luapula & 11907 & $1071(9.0)$ & $2.90(2.72,3.09)$ & $2.77(2.56,2.99)$ \\
\hline Lusaka & 14446 & $375(2.6)$ & $0.78(0.71,0.86)$ & $0.88(0.79,0.99)$ \\
\hline Northern & 16288 & $672(4.1)$ & $1.26(1.17,1.36)$ & $1.13(1.03,1.23)$ \\
\hline North-Western & 8788 & $597(6.8)$ & $2.14(1.97,2.32)$ & $2.19(1.99,2.42)$ \\
\hline Southern & 17316 & $431(2.5)$ & $0.75(0.68,0.82)$ & $0.81(0.73,0.89)$ \\
\hline Central & 12312 & $336(2.7)$ & $0.82(0.74,0.91)$ & $0.81(0.72,0.90)$ \\
\hline \multicolumn{5}{|l|}{ Current employment status } \\
\hline unpaid formal worker & 39383 & $1204(3.1)$ & 1 & 1 \\
\hline paid employee & 10915 & $767(7.0)$ & $1.23(1.17,1.30)$ & $1.36(1.27,1.46)$ \\
\hline employer/self employed & 28843 & $2561(8.9)$ & $1.59(1.52,1.65)$ & $1.03(0.98,1.08)$ \\
\hline
\end{tabular}

suffered at workplace.

Note: Numbers not adding up due to missing information.

well as a baseline on which to base statistical targets for improvement. There was geographic variation in the distribution of reported disease, with higher reported prevalence in specific provinces. This information could be useful to the Ministry of Labour to identify areas in specific need of attention, especially in terms of surveillance, enforcement or revision of work policies.

\section{Acknowledgements}

The data used in this study was made available to us from Central Statistical Office, Government of the Republic of Zambia. We thank Amanda Ryan for her input into the design of the questionnaire and suggestions on how to analyze the data.

\section{Author details}

'Department of Public Health, Division of Community Health, College of Medicine, University of Malawi, Blantyre, Malawi. ${ }^{2}$ Division of Epidemiology and Biostatistics, Graduate School of Public Health, San Diego State

University, San Diego, California, USA. ${ }^{3}$ Department of Community Medicine, School of Medicine, University of Zambia, Lusaka, Zambia.

\section{Authors' contributions}

ASM participated in data collection, interpretation of findings and writing the manuscript. ER participated in the decision of which aspects of the data to analyze, interpretation of data and drafting of the manuscript. SS participated in data collection, analysis and drafting of manuscript. All authors approved the final draft of the manuscript. 


\section{Competing interests}

The authors declare that they have no competing interests.

Received: 10 March 2010 Accepted: 27 October 2010

Published: 27 October 2010

\section{References}

1. Phillips EK, Owusu Ofori A, Jagger J: Bloodborne pathogen exposure risk among surgeons in sub-Saharan Africa. Infect Control Hosp Epidemiol 2007, 28:1334-1336.

2. M'ikanatha NM, Imunya SG, Fisman DN, Julian KG: Sharpdevice injuries and perceived risk of infection with bloodborne pathogens among healthcare workers in rural Kenya. Infect Control Hosp Epidemiol 2007, 28:761-763.

3. van Oosterhout JJ, Nyirenda M, Beadsworth MB, Kanyangalika JK, Kumwenda JJ, Zijlstra EE: Challenges in HIV postexposure prophylaxis for occupational injuries in a large teaching hospital in Malawi. Trop Doct 2007, 37:4-6.

4. Ismail NA, Aboul Ftouh AM, El Shoubary WH: Safe injection practice among health care workers, Gharbiya, Egypt. J Egypt Public Health Assoc 2005, 80:563-583.

5. Braka F, Nanyunja M, Makumbi I, Mbabazi W, Kasasa S, Lewis RF: Hepatitis B infection among health workers in Uganda: evidence of the need for health worker protection. Vaccine 2006, 24:6930-6937.

6. Chitra GA, Muraleedharan VR, Swaminathan T, Veeraraghavan D: Use of pesticides and its impact on health of farmers in South India. Int J Occup Environ Health 2006, 12:228-233.

7. Litchfield $\mathrm{MH}$ : Estimates of acute pesticide poisoning in agricultural workers in less developed countries. Toxicol Rev 2005, 24:271-278.

8. Loewenson R: Globalization and occupational health: a perspective from southern Africa. Bull World Health Organ 2001, 79:863-868.

9. WHO: Situational analysis for health at work and development of the global working life.[http://www.who.int/occupational_health/publications/ globstrategy/en/index4.html].

10. Siziya S, Muula AS, Ryan A, Rudatsikira E: Compensation patterns following occupational injuries in Zambia: results from the Zambian Labour Force Survey. International Archives of Medicine 2010, 3:19.

11. Sabitu K, lliyasu Z, Dauda MM: Awareness of occupational hazards and utilization of safety measures among welders in Kaduna metropolis, Northern Nigeria. Ann Afr Med 2009, 8:46-51.

12. Sprince NL, Pospisil S, Peek Asa C, Whitten PS, Zwerling C: Occupational injuries among workers with diabetes: the National Health Interview Survey, 1997-2005. J Occup Environ Med 2008, 50:804-808.

13. Soori H, Rahimi M, Mohseni H: Occupational stress and work-related unintentional injuries among Iranian car manufacturing workers. East Mediterr Health J 2008, 14:697-703.

doi:10.1186/1756-0500-3-272

Cite this article as: Muula et al:: Occupational illnesses in the 2009

Zambian labour force survey. BMC Research Notes 2010 3:272.

\section{Submit your next manuscript to BioMed Central and take full advantage of:}

- Convenient online submission

- Thorough peer review

- No space constraints or color figure charges

- Immediate publication on acceptance

- Inclusion in PubMed, CAS, Scopus and Google Scholar

- Research which is freely available for redistribution

Submit your manuscript at www.biomedcentral.com/submit
Biomed Central 